\title{
Extraosseous Calcification
}

\author{
EVIDENCE FOR ABNORMAL PYROPHOSPHATE \\ METABOLISM IN UREMIA
}

\author{
Allen C. Alfrey, Clive C. Solomons, Jenny Ciricillo, and \\ NANCY L. MiLleR
}

From the Renal Section, Denver Veterans Administration Hospital, the

Division of Renal Medicine, and Department of Pediatrics, University of

Colorado Medical Center, Denver, Colorado 80220

A в S T R A C T The inorganic constituents and crystalline features of extraosseous calcium-phosphate deposits obtained from dialyzed uremic and hypercalcemic patients were studied. Visceral calcification (heart, lung, and kidney) in hypercalcemic patients exhibited either an amorphous or apatitic X-ray diffraction pattern. Uremic visceral calcification consistently gave an amorphous diffraction pattern. Although the calcium content of uremic and hypercalcemic visceral deposits was similar, other inorganic constituents were different. The mean pyrophosphate was $11 \pm 11.8$ and magnesium $4.91 \pm 3.86$ $\mathrm{mg} / \mathrm{g}$ in the uremic group as compared to $0.92 \pm 0.24$ and $1.36 \pm 1.26 \mathrm{mg} / \mathrm{g}$ in the hypercalcemic group $(P<0.025)$. After incineration hypercalcemic visceral deposits having an amorphous diffraction pattern were found to generate pyrophosphate supporting the presence of brushite in these deposits. The small amount of pyrophosphate in apatitic deposits from both uremic and hypercalcemic patients actually decreased after incineration and the pyrophosphate content of uremic visceral deposits was unchanged by incineration.

It is concluded that in hypercalcemic patients the initial visceral deposit is brushite which is subsequently transformed to apatite. Arterial and tumoral calciumphosphate deposits in uremic patients were also apatite. Uremic visceral calcium-phosphate deposits are an unique mineral high in magnesium with approximately $30 \%$ of the phosphorus present as pyrophosphate. The high pyrophosphate content of these deposits could alter their crystalline structure and prevent the transformation to apatite. The infrared features, high magnesium content of the deposit, and resistance of pyrophosphate in the deposit to hydrolysis by pyrophosphatase suggests

Received for publication 8 August 1975 and in revised form 29 October 1975. that the pyrophosphate may be deposited as the magnesium salt.

\section{INTRODUCTION}

Three distinct clinical types of extraosseous calcifications are found in uremic patients: $(a)$ calcification in median size arteries, (b) periarticular (tumoral) calcification, and (c) visceral calcification (heart, lung, and kidney). The fact that severe visceral calcification can occur in patients who are free of arterial and tumoral calcification as well as the converse, where severe arterial or tumoral calcification occurs in patients who are free of visceral calcification strongly suggests that the etiology of these deposits is different. Massry et al. (1) have previously suggested that the increased calcium content in uremic patients' skin is a consequence of the hyperparathyroid state. However, Contiguglia et al. (2) were unable to show any relationship between parathyroid size and the development of pulmonary, myocardial, and skeletal muscle calcification. Although it is widely accepted that tumoral calcification can be prevented or cured $(3,4)$ by phosphate depletion it is unknown whether such treatment has any effect on visceral calcification. In spite of the routine use of phosphate-binding gels and maintaining serum phosphate at $7 \mathrm{mg} / 100 \mathrm{ml}$ or less, a prospective study showed that approximately $50 \%$ of dialysis patients developed visceral calcification (5) whereas none developed arterial or tumoral deposits during the study period.

The chemical composition and crystalline nature of uremic visceral calcification has also been found to be different from arterial and periarticular calcium-phosphate deposits (6). An unexpected finding was that uremic visceral calcium-phosphate deposits uniformly 
exhibited an amorphous X-ray diffraction pattern (6). It has previously been felt that the initial extraosseous calcium-phosphate deposit is brushite $\left(\mathrm{CaHPO} \cdot 2 \mathrm{H}_{2} \mathrm{O}\right)$. Since brushite is stable at a $\mathrm{pH}$ of 6.2 but is rapidly transformed to apatite at a $\mathrm{pH}$ of 6.9 or higher, it has been stated that apatite $\left[\mathrm{Ca}_{10}\left(\mathrm{PO}_{4}\right)_{8} \cdot(\mathrm{OH})_{2}\right]$ is the only solid phase of calcium and phosphate that can form under physiological conditions (7). This would suggest that an inhibitor or stabilizer such as pyrophosphate $\left(\mathrm{P}_{2} \mathrm{O}_{7}\right)^{1}$ is present in uremic visceral calcification which prevents the transformation of these deposits to apatite.

The present study was carried out to fully characterize the inorganic constituents of uremic visceral, tumoral, and arterial calcification. To determine if the crystalline characteristics of visceral calcification are primarily determined by the matrix within which it is formed, visceral calcification obtained from hypercalcemic patients was also studied to compare with the uremic deposits.

\section{METHODS}

Tissues (heart, lung, kidney, skeletal muscle, dura, arterial, and periarticular deposits) were obtained from 11 dialyzed uremic patients previously shown to have calcifications and 3 patients who had hypercalcemia. The etiology of the hypercalcemia was different in all of the latter three patients. Two patients had acute hypercalcemia shortly before death which was secondary to multiple myeloma in one and rhabdomyolysis in the second. The third patient had long-standing undiagnosed hyperparathyroidism. At time of death these patients had normal or only moderately reduced renal function. Tissues for comparison were obtained from two control subjects who had experienced sudden death and three dialyzed uremic patients without calcification.

Tissues were kept in a frozen state until analyzed. The tissues were then dried, ground into a fine powder, and extracted four times with $2 \mathrm{ml}$ of ether-petroleum ether (1/1 $\mathrm{vol} / \mathrm{vol})$. For chemical analysis the dry defatted tissue was digested by boiling in $1 \mathrm{ml}$ nitric acid for $1 \mathrm{~h}$. The resulting clear liquid was diluted to $20 \mathrm{ml}$ with deionized water. Calcium, magnesium, and phosphate were determined by previously reported methods (2).

Five tissues with heavy calcification obtained from uremic and hypercalcemic patients were dried at room temperature and analyzed for multiple trace elements using an X-ray fluorescence technique (8).

For $\mathrm{P}_{2} \mathrm{O}_{7}$ determination, $25 \mathrm{mg}$ of the finely ground dry, defatted tissue, or tissue after ashing at $550^{\circ} \mathrm{C}$ was placed in $2 \mathrm{ml}$ of a $15 \%$ EDTA solution with $\mathrm{pH}$ adjusted to 7.4 for $12 \mathrm{~h}$ and $\mathrm{P}_{2} \mathrm{O}_{7}$ determinations were performed on the supernate. The EDTA extraction of calcium and magnesium from the dry tissue has been shown to be complete as determined by ashing and analyzing the residue. $1 \mathrm{ml}$ of the EDTA solution was applied to a resin column (Bio-Rad AG $1 \times 10,100-200$ mesh, chloride form, Bio-Rad Laboratories, Richmond, Calif.) and the orthophosphate fraction eluted with $100 \mathrm{ml}$ of $0.1 \mathrm{~mol} / \mathrm{liter}$ potassium chloride. The $\mathrm{P}_{2} \mathrm{O}_{7}$ was then eluted with $1.1 \mathrm{~mol} /$ liter hydrochloric acid. The first $6 \mathrm{ml}$ of the acid was discarded and subsequent 4-10 ml-fractions collected. Concentrated $\mathrm{HCl}, 0.3 \mathrm{ml}$, was added to the first three fractions. The proteins were eluted

${ }^{1}$ Abbreviation used in this paper: $\mathrm{P}_{2} \mathrm{O}_{7}$, pyrophosphate. in the first $30 \mathrm{ml}$ of the $\mathrm{KCl}$ fraction and did not contaminate the orthophosphate or $\mathrm{P}_{2} \mathrm{O}_{7}$ peaks. The hydrochloric acid fractions were hydrolyzed at $100^{\circ}-120^{\circ} \mathrm{C}$ for $60 \mathrm{~min}$ before colorimetric analysis for phosphate was performed. The phosphate was determined by a modification of the standard method of Chen et al. (9). Recovery of $\mathrm{P}_{2} \mathrm{O}_{7}$ with this method has been consistently in the range of $95-105 \%$ as determined with ${ }^{32} \mathrm{P}$-labeled $\mathrm{P}_{2} \mathrm{O}_{7}$. The specific activity of each fraction in the $\mathrm{P}_{2} \mathrm{O}_{7}$ peak has been found not to differ significantly from unity over a wide range of $\mathrm{P}_{2} \mathrm{O}_{7}$ concentrations and amounts of labels used. Extraction of phospholipids with a chloroform-methanol mixture did not alter the $\mathrm{P}_{2} \mathrm{O}_{7}$ values and the addition of pure lecithin, sphingomyelin, and phosphatidylethanolamine likewise had no effect on the $\mathrm{P}_{2} \mathrm{O}_{7}$ recoveries. Treatment with yeast pyrophosphatase (EC 3.6.1.1) completely removed the $\mathrm{P}_{2} \mathrm{O}_{7}$ peak. To show that nucleotides were not responsible for falsely increasing $\mathrm{P}_{2} \mathrm{O}_{7}$ levels, tissue samples high in $\mathrm{P}_{2} \mathrm{O}_{7}$ were pretreated with charcoal. This did not alter the $\mathrm{P}_{2} \mathrm{O}_{7}$ determination. This method for determining $\mathrm{P}_{2} \mathrm{O}_{7}$ has been used successfully by two other investigators $(10,11), \mathrm{P}_{2} \mathrm{O}_{7}$ and orthophosphate content of the various tissue is reported as milligram $P$ for each compound.

For infrared analysis $1 \mathrm{mg}$ of dry sample was mixed with $300 \mathrm{mg} \mathrm{KBr}$ and pressed into a clear disk using 12 tons

TABLE I

$\mathrm{P}_{2} \mathrm{O}_{7}$ Content of Visceral Tissue

\begin{tabular}{|c|c|c|c|c|}
\hline & $\mathrm{Ca}$ & $\mathbf{M g}$ & $\mathrm{PO}_{4}(\mathrm{P})$ & $\mathrm{P}_{2} \mathrm{O}_{7}(\mathrm{P})$ \\
\hline & \multicolumn{4}{|c|}{$m g / g$ dry tissue } \\
\hline \multicolumn{5}{|c|}{ Controls } \\
\hline 1 & 0.70 & 0.65 & 2.5 & 0.85 \\
\hline 2 & 0.40 & 0.60 & 2.0 & 0.37 \\
\hline 3 & 0.50 & 0.50 & 3.1 & 1.40 \\
\hline 4 & 0.90 & 0.50 & 2.6 & 0.53 \\
\hline 5 & 0.50 & 0.60 & 2.4 & 0.85 \\
\hline Mean & 0.60 & 0.57 & 2.5 & 0.80 \\
\hline $\mathrm{SD}$ & 0.20 & 0.07 & 0.4 & 0.40 \\
\hline \multicolumn{5}{|c|}{ Hypercalcemic } \\
\hline 1 & 4.2 & 0.76 & 5.4 & 0.56 \\
\hline 2 & 4.1 & 0.65 & 4.4 & 0.89 \\
\hline 3 & 7.4 & 1.08 & 6.7 & 1.00 \\
\hline 4 & 20.0 & 0.72 & 12.0 & 0.95 \\
\hline 5 & 160.0 & 3.60 & 123.0 & 1.21 \\
\hline Mean & 39.1 & 1.36 & 30.3 & 0.92 \\
\hline SD & 67.9 & 1.26 & 51.9 & 0.24 \\
\hline \multicolumn{5}{|l|}{ Uremic } \\
\hline 1 & 10.4 & 1.6 & 8.3 & 3.0 \\
\hline 2 & 12.5 & 1.8 & 9.5 & 3.1 \\
\hline 3 & 15.0 & 2.1 & 9.4 & 3.0 \\
\hline 4 & 27.0 & 2.9 & 15.3 & 4.6 \\
\hline 5 & 46.8 & 5.0 & 26.0 & 7.0 \\
\hline 6 & 65.0 & 6.3 & 38.0 & 7.5 \\
\hline 7 & 81.0 & 6.5 & 50.0 & 32.5 \\
\hline 8 & 120.0 & 13.1 & 56.0 & 27.0 \\
\hline Mean & 47.2 & 4.91 & 26.6 & 11.0 \\
\hline $\mathrm{SD}$ & 39.2 & 3.86 & 19.2 & 11.8 \\
\hline
\end{tabular}




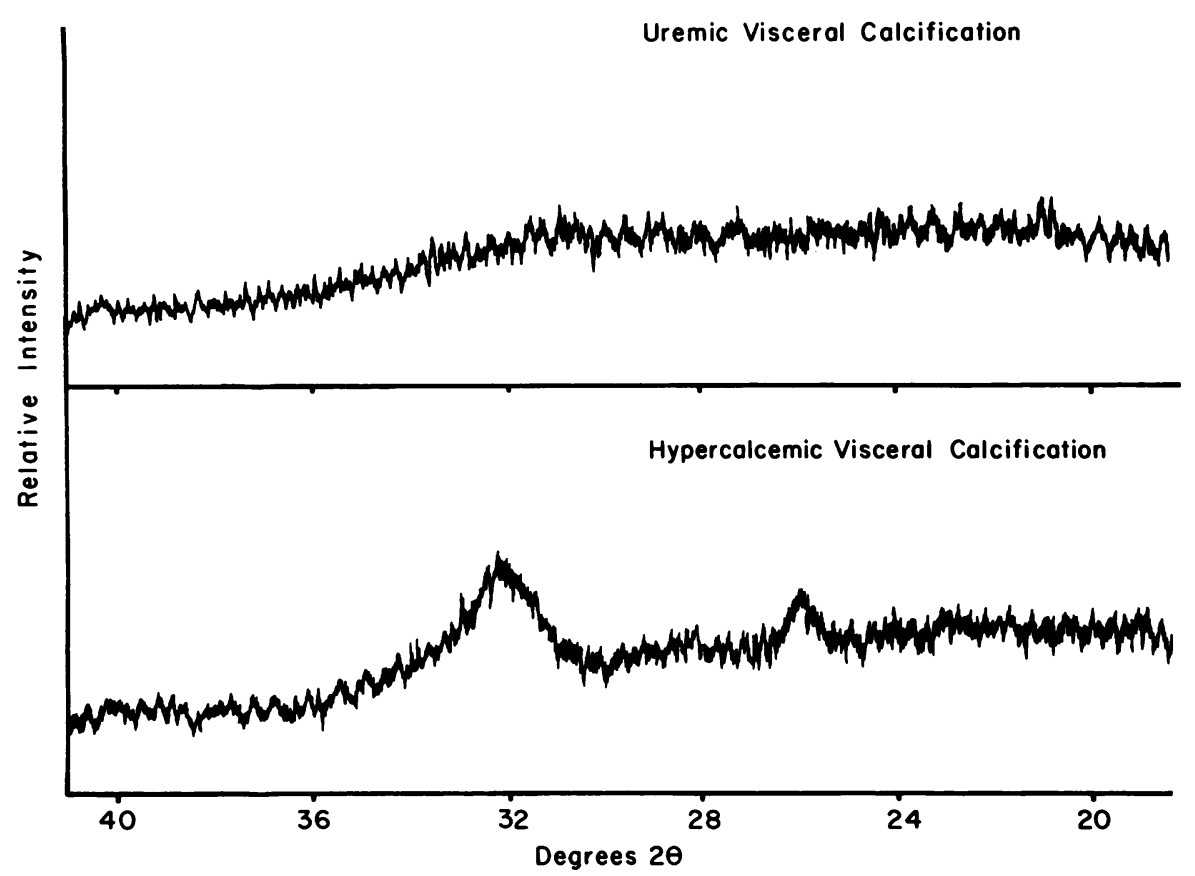

FIGURE 1 X-ray diffraction patterns obtained on untreated hypercalcemic and uremic visceral calcium-phosphate deposits. Both tissues were extensively calcified. No diffraction peaks (amorphous patterns) are present in the uremic deposit. Apatitic peaks are present in the hypercalcemic deposit.

pound per square inch in a vacuum. The sample was then mounted in a Perkin-Elmer Infrared Spectrophotometer (Perkin-Elmer Ultek Inc., Palo Alto, Calif.) and scanned from 4,000 to $600 \mathrm{~cm}^{-1}(2-15 \mu \mathrm{m})$.

Powder X-ray diffraction studies were carried out with a Norelco diffractometer (North American Philips Co., Inc., New York) equipped with a graphite crystal monochrometer. The 2 - $\theta$-diffraction range covered was $12^{\circ}-60^{\circ}$ at a scanning speed of $1^{\circ}$ min. Patterns were interpreted by comparing them with the American Society of Testing Materials index cards.

The brushite content of the various deposits was estimated by determining the $\mathrm{PO}_{4}$ and $\mathrm{P}_{2} \mathrm{O}_{7}$ content of the deposits before and after incineration at $550^{\circ} \mathrm{C}$. Although Greenfield et al. (12) have recently criticized the use of the pyrolytic method for estimating $\mathrm{HPO}_{4}$ content of carbonate-containing apatites, their studies would suggest that this method is valid for estimating the $\mathrm{HPO}_{4}$ content of amorphous calcium-phosphate deposits.

\section{RESULTS}

X-ray diffraction studies were carried out on all tissues. The dialyzed uremic visceral calcification, and the three tissues with the lowest calcium content obtained from the hypercalcemic group all gave an amorphous X-ray diffraction pattern (Fig. 1). An apatitic diffraction pattern was found in the two tissues with the highest calcium content in the hypercalcemic group (Fig. 1) and in the arterial and periarticular deposits obtained from uremic patients.
The calcium, magnesium, orthophosphate, and $\mathrm{P}_{2} \mathrm{O}_{7}$ content of the dry tissues are shown in Table I. The calcium and orthophosphate content was significantly higher in the uremic visceral calcification than the control group but not different from the hypercalcemic group (Table $\mathrm{I}$ ). The mean $\mathrm{P}_{2} \mathrm{O}_{7}$ was 10.96 and magnesium $4.91 \mathrm{mg} / \mathrm{g}$ in the uremic visceral calcification as compared to 0.92 and $1.36 \mathrm{mg} / \mathrm{g}$ in the hypercalcemic group $(P<0.025)$. There were not enough tissues in the uremic, arterial, or periarticular groups for statistical comparison. However, these deposits were low in both magnesium and $\mathrm{P}_{2} \mathrm{O}_{7}$.

The thermochemical properties of the various deposits were studied to more fully characterize their crystalline structure. The brushite content of the dry deposits was estimated by determining orthophosphate and $\mathrm{P}_{2} \mathrm{O}_{7}$ content before and after incineration. The results are given in Table II. In the hypercalcemic visceral calcification, which gave an amorphous $\mathrm{X}$-ray diffraction pattern, there was a significantly higher $\mathrm{P}_{2} \mathrm{O}_{7}$ and lower $\mathrm{PO}$. content after incineration supporting the presence of brushite in these deposits. In contrast, the $\mathrm{P}_{2} \mathrm{O}_{7}$ content did not significantly change in the uremic visceral calcium-phosphate deposits after incineration. In the tissues demonstrating an apatitic diffraction pattern, with the exception of one hypercalcemic visceral deposit, the $\mathrm{P}_{2} \mathrm{O}_{7}$ content actually fell after incineration (Table II). 
TABLE II

Effect of Incinceration on $\mathrm{P}_{2} \mathrm{O}_{7}$ Generation

\begin{tabular}{|c|c|c|c|c|}
\hline \multirow{2}{*}{$\begin{array}{c}\text { X-ray diffraction } \\
\text { pattern } \\
\text { Dry tissue }\end{array}$} & \multicolumn{2}{|c|}{$\mathrm{P}_{2} \mathrm{O}_{7}(\mathrm{P})$} & \multicolumn{2}{|c|}{$\mathrm{PO}_{4}(\mathrm{P})$} \\
\hline & Before & After $550^{\circ} \mathrm{C}$ & Before & After $550^{\circ} \mathrm{C}$ \\
\hline & \multicolumn{4}{|c|}{$m g / g$ drytissue } \\
\hline \multicolumn{5}{|l|}{ Amorphous } \\
\hline \multicolumn{5}{|l|}{ Hypercalcemic } \\
\hline 1 & 0.56 & 3.0 & 5.4 & 3.4 \\
\hline 2 & 1.00 & 5.0 & 6.7 & 5.6 \\
\hline 3 & 0.89 & 5.7 & 4.4 & 2.8 \\
\hline \multicolumn{5}{|l|}{ Uremic } \\
\hline 1 & 7.0 & 6.5 & 26 & 31 \\
\hline 2 & 3.0 & 3.0 & 8.3 & 11.3 \\
\hline 3 & 4.6 & 5.6 & 15.3 & 25.9 \\
\hline \multicolumn{5}{|l|}{ Apatitic } \\
\hline \multicolumn{5}{|l|}{ Hypercalcemic } \\
\hline 1 & 0.95 & 2.3 & 12 & 15 \\
\hline 2 & 1.71 & 0.28 & 123 & 125 \\
\hline \multicolumn{5}{|l|}{ Uremic } \\
\hline 1 & 3.5 & 0.4 & 109 & 126 \\
\hline 2 & 0.64 & 0.20 & 115 & 117 \\
\hline 3 & 1.36 & 1.20 & 108 & 111 \\
\hline
\end{tabular}

The postincineration $\mathrm{X}$-ray diffraction patterns were also different in the three groups. In the hypercalcemic group demonstrating an amorphous X-ray diffraction pattern before incineration, the major peaks of $\mathrm{P}_{2} \mathrm{O}_{7}$ were found after incineration (Fig. 2). In the uremic visceral calcification group (after incineration) major peaks of whitlockite and minor peaks of $\mathrm{P}_{2} \mathrm{O}_{7}$ were repeatedly found. In tissues which had an apatitic pattern only apatite peaks were found after incineration. These studies give support for the validity of the chemical method for determining $\mathrm{P}_{2} \mathrm{O}_{7}$ in that those tissues with high $\mathrm{P}_{2} \mathrm{O}_{7}$ content also demonstrated $\mathrm{X}$-ray diffraction patterns of $\mathrm{P}_{2} \mathrm{O}_{7}$.

Additional confirmation for the presence of $\mathrm{P}_{2} \mathrm{O}_{7}$ in the untreated uremic visceral calcification and incinerated hypercalcemic visceral calcification is the demonstration of $\mathrm{P}-\mathrm{O}$ bondings with infrared techniques in only these two groups of tissues (Fig. 3). The similarity between the infrared pattern of uremic visceral calcification and magnesium $\mathrm{P}_{2} \mathrm{O}_{7}$ is striking suggesting that the $\mathrm{P}_{2} \mathrm{O}_{7}$ might be deposited as the magnesium salt (Fig. 4).

To determine if the $\mathrm{P}_{2} \mathrm{O}_{7}$ present in uremic visceral calcification was resistant to pyrophosphatase the dry deposit was incubated with $30 \mathrm{U}$ of yeast inorganic pyrophosphatase in a Tris buffer solution at $\mathrm{pH}$ 7.2. The results are given in Table III. Although the enzyme was shown to be capable of hydrolyzing $\mathrm{Na}_{4} \mathrm{P}_{2} \mathrm{O}_{7}$ the $\mathrm{P}_{2} \mathrm{O}_{7}$ in the uremic deposit was totally resistant to this enzyme.

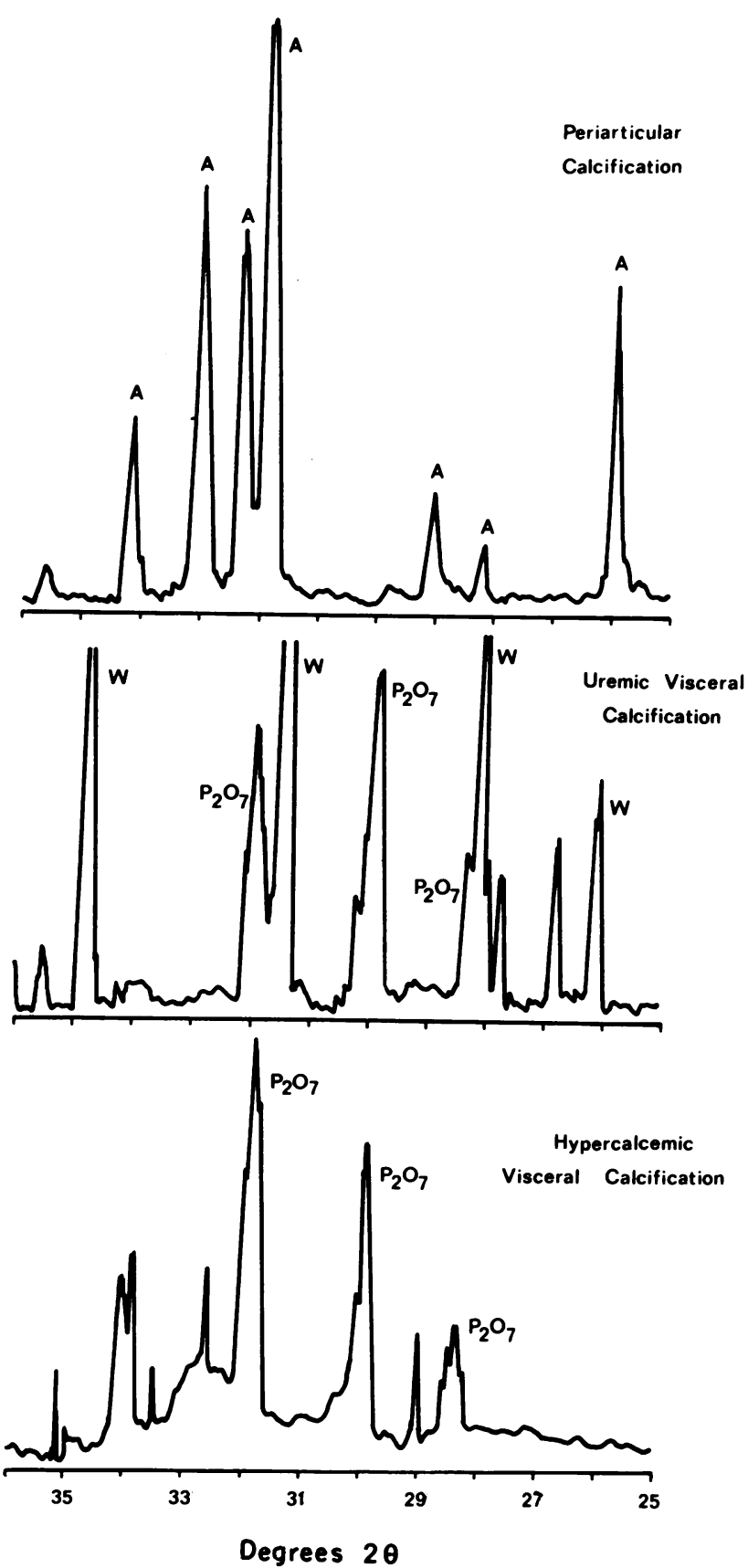

FIGURE 2 Postincineration $\mathrm{X}$-ray diffraction patterns obtained in uremic periarticular and visceral deposits and hypercalcemic visceral deposits. Apatitic peaks are marked with an $\mathrm{A}$, whitlockitic with a $\mathrm{W}$, and pyrophosphate with $\mathrm{P}_{2} \mathrm{O}_{7}$.

To determine if other inorganic constituents were different in the various types of calcium-phosphate deposits a trace element profile using an X-ray fluorescence method was obtained on five tissues. Results are shown 


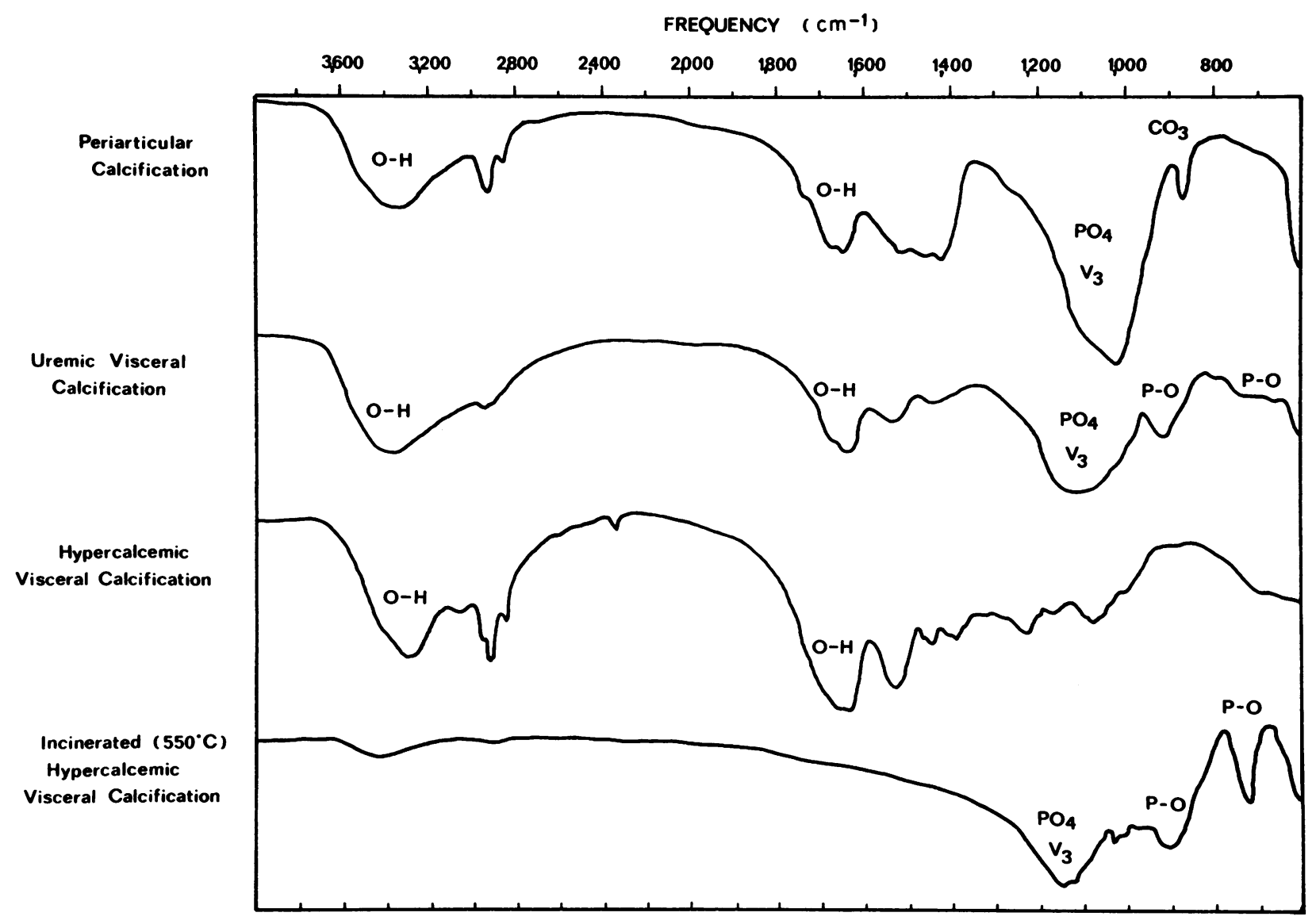

FIGURE 3 Infrared patterns obtained in untreated periarticular, uremic visceral, hypercalcemic visceral, and postincinerated hypercalcemic visceral deposits. The P-O bonding is present only in the untreated uremic and postincinerated hypercalcemic visceral deposits.

in Table IV. The only difference between the uremic visceral calcification and other forms of calcification was a slightly higher strontium and lower zinc content.

\section{DISCUSSION}

Three distinct types of extraosseous calcium-phosphate deposits have been characterized in uremic and hypercalcemic patients. Visceral deposits of moderate severity which developed in two patients with acute hypercalcemia were shown to generate $\mathrm{P}_{2} \mathrm{O}_{7}$ after incineration supporting the presence of brushite in these deposits. In a patient with chronic hypercalcemia, who had extensive visceral calcification, the deposits were shown to be apatitic by infrared and $\mathrm{X}$-ray diffraction techniques. These findings would support the previous concept that in hypercalcemic states brushite is initially deposited. However, at the body's $\mathrm{pH}$ it is eventually transformed to apatite (7).

Periarticular (tumoral) and arterial calcification present in uremic patients has also been shown to be apatitic.
The small amount of $\mathrm{P}_{2} \mathrm{O}_{7}$ present in these deposits actually decreased after incineration. Greenfield et al. (12) have previously shown that $\mathrm{P}_{2} \mathrm{O}_{7}$ in carbonate-containing apatite, but not in amorphous calcium-phosphate deposits, is destroyed with incineration. Thus, in apatitic deposits it is not possible, using the pyrolytic method, to determine if brushite is also present.

Uremic visceral calcification is an unique mineral different from the above types of calcium-phosphate deposits. Irrespective of the degree of calcification, and probably chronicity, apatitic diffraction patterns have never been found; instead these deposits consistently give an amorphous $\mathrm{X}$-ray diffraction pattern. The chemical consituents of these deposits is also different from the other types of calcium-phosphate deposits. The magnesium and $\mathrm{P}_{2} \mathrm{O}_{7}$ content is very high. Neither additional $\mathrm{P}_{2} \mathrm{O}_{7}$ is generated nor existing $\mathrm{P}_{2} \mathrm{O}_{7}$ destroyed by incineration. Thus brushite would not appear to be present in these deposits. The $\mathrm{X}$-ray diffraction peaks of whitlockite in association with $\mathrm{P}_{2} \mathrm{O}_{7}$ is unlike the pattern ob- 


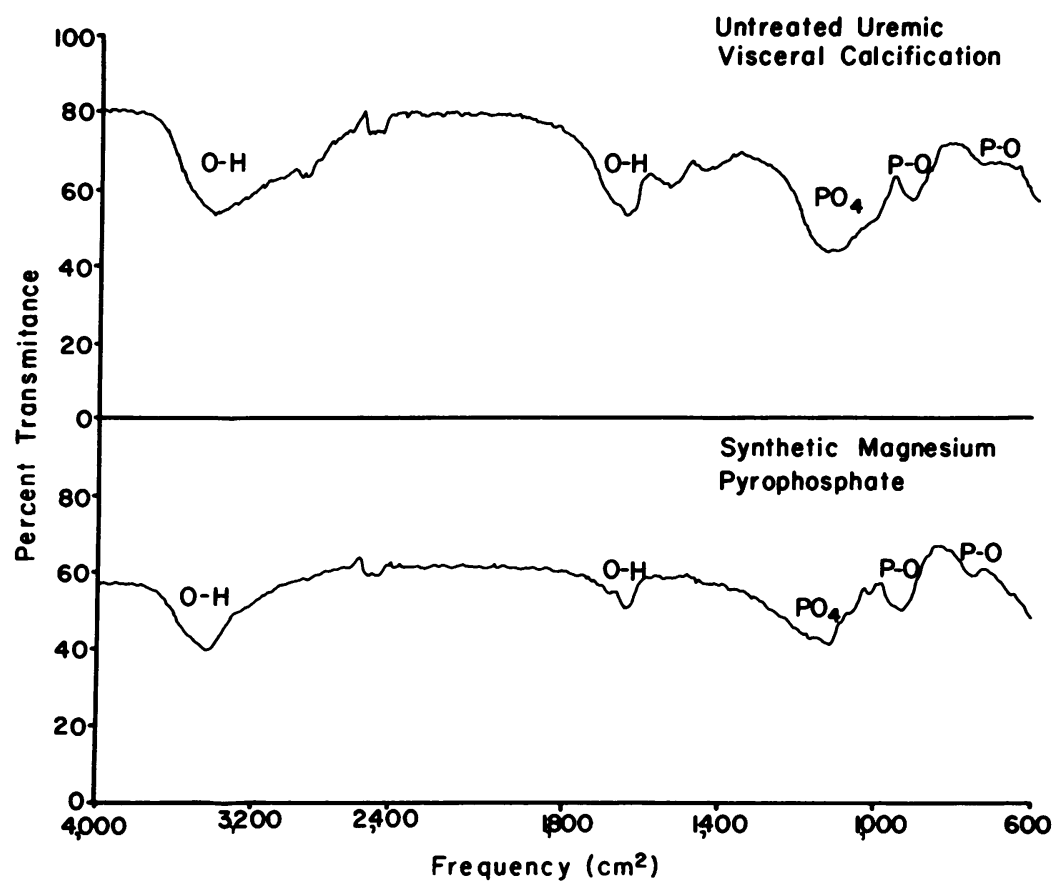

FIGURE 4 Infrared patterns of uremic visceral calcification and synthetic magnesium $\mathrm{P}_{2} \mathrm{O}_{7}$.

tained in other types of calcium-phosphate deposits after incineration. These different crystalline features and inorganic constituents of uremic visceral calcification are not a consequence of the matrix on which the deposits form since hypercalcemic visceral calcification involves the same organs.

The finding that approximately $30 \%$ of the phosphorus present in uremic visceral calcification is $\mathrm{P}_{2} \mathrm{O}_{7}$ represents the first hard evidence that $\mathrm{P}_{2} \mathrm{O}_{7}$ is involved in the patho-

TABLE III

Effect of Pase on $\mathrm{P}_{2} \mathrm{O}_{7}$

\begin{tabular}{|c|c|c|c|c|}
\hline \multirow[b]{3}{*}{ Time } & \multicolumn{4}{|c|}{ Uremic visceral calcification } \\
\hline & \multicolumn{2}{|c|}{ PO، OD } & \multicolumn{2}{|c|}{$\mathrm{P}_{2} \mathrm{O}_{7} \mathrm{OD}$} \\
\hline & $\begin{array}{l}\text { Without } \\
\text { pase }\end{array}$ & $\begin{array}{l}\text { With } \\
\text { pase }\end{array}$ & $\begin{array}{l}\text { Without } \\
\text { pase }\end{array}$ & $\begin{array}{l}\text { With } \\
\text { pase }\end{array}$ \\
\hline $30 \mathrm{~min}$ & 516 & 470 & 5,249 & 5,751 \\
\hline $1 \mathrm{~h}$ & 522 & 475 & 5,624 & 5,230 \\
\hline \multirow[t]{2}{*}{ Mean } & 519 & 473 & 5,437 & 5,491 \\
\hline & \multicolumn{2}{|c|}{$\mathrm{Na}_{4} \mathrm{P}_{2} \mathrm{O}_{7}$} & \multicolumn{2}{|c|}{$\mathrm{Na}_{4} \mathrm{P}_{2} \mathrm{O}_{7}$} \\
\hline $10 \mathrm{~min}$ & 23 & 400 & 299 & 12 \\
\hline $30 \mathrm{~min}$ & 67 & 342 & 301 & 35 \\
\hline $1 \mathrm{~h}$ & 23 & 378 & 228 & 16 \\
\hline Mean & 38 & 373 & 276 & 21 \\
\hline
\end{tabular}

* Pase, inorganic pyrophosphatase. genesis of the disordered calcium metabolism present in uremic patients. Since $\mathrm{P}_{2} \mathrm{O}_{7}$ is known to stabilize calcium-phosphate deposits preventing the transformation to apatite $(13,14)$ it seems likely that the $\mathrm{P}_{2} \mathrm{O}_{7}$ is

TABLE IV

Inorganic Constituents of Extraosseous CalciumPhosphate Deposits

\begin{tabular}{|c|c|c|c|c|c|}
\hline & \multicolumn{4}{|c|}{ Uremic } & \multirow{2}{*}{$\begin{array}{l}\text { Hyper- } \\
\text { calcemi } \\
\text { visceral }\end{array}$} \\
\hline & Arterial & $\begin{array}{c}\text { Peri- } \\
\text { articular }\end{array}$ & \multicolumn{2}{|c|}{ Visceral } & \\
\hline & \multicolumn{5}{|c|}{$m g / k g d r y w t$} \\
\hline $\mathrm{Ca}$ & 226,000 & 222,000 & 81,000 & 120,000 & 160,000 \\
\hline $\mathrm{Mg}$ & 2,700 & 3,900 & 6,500 & 13,100 & 3,600 \\
\hline $\mathrm{P}_{2} \mathrm{O}_{7}$ & 1,360 & 640 & 32,500 & 27,000 & 1,210 \\
\hline $\mathrm{Fe}$ & 313 & 13 & 33 & 50 & ND \\
\hline $\mathrm{Cu}$ & ND & ND & ND & ND & ND \\
\hline $\mathrm{Zn}$ & 232 & 230 & 93 & 79 & 227 \\
\hline As & 7 & ND & ND & ND & ND \\
\hline $\mathrm{Se}$ & ND & ND & ND & ND & $\mathrm{ND}$ \\
\hline $\mathrm{Br}$ & 30 & 636 & 8 & 8 & 37 \\
\hline $\mathrm{Rb}$ & 6 & ND & 2 & 3 & 6 \\
\hline $\mathrm{Sr}$ & 258 & 76 & 240 & 272 & 57 \\
\hline $\mathrm{Zr}$ & ND & ND & ND & ND & ND \\
\hline Mo & 2 & ND & ND & ND & ND \\
\hline $\mathrm{Cd}$ & 6 & ND & ND & ND & ND \\
\hline Sn & 18 & ND & 8 & 10 & 6 \\
\hline $\mathrm{Pb}$ & 15 & ND & 8 & 24 & 18 \\
\hline
\end{tabular}

$\mathrm{ND}=$ non detectable. 
directly responsible for the altered crystalline structure of visceral calcification in uremic patients. This stabilizing effect of $\mathrm{P}_{2} \mathrm{O}_{7}$ on calcium-phosphate deposits may have other implications as well. Although it is well recognized that tumoral calcification, which is apatitic and low in $\mathrm{P}_{2} \mathrm{O}_{7}$ is rapidly mobilized after reduction of the $\mathrm{Ca} \times \mathrm{P}$ product $(3,4)$ the high $\mathrm{P}_{2} \mathrm{O}_{7}$ content of visceral calcification could prevent its mobilization even when the milieu within which it was formed is normalized as would occur after transplantation. This would have major implication since visceral calcification in uremic patients can result in marked disturbance in both pulmonary and myocardial function $(5,15)$.

We have been impressed that visceral calcification usually develops in patients who are free of tumoral and arterial deposits suggesting different pathogenic mechanisms for these types of deposits. Furthermore, factors which have been shown to play a role in the pathogenesis of vascular and tumoral calcium-phosphate deposits such as hyperparathyroidism (1) and increased calcium-phosphate products $(3,16)$ have not been shown to correlate with the development of visceral calcium-phosphate deposits $(2,5)$. Besides the theoretical importance of $\mathrm{P}_{2} \mathrm{O}_{7}$ in altering crystal structure and stability it also seems possible that $\mathrm{P}_{2} \mathrm{O}_{7}$ may at least be partly responsible for the development of visceral calcium-phosphate deposits. Russell et al. (17) have shown increased plasma $\mathrm{P}_{2} \mathrm{O}_{7}$ levels in some uremic patients and David et al., (10) found elevated serum $\mathrm{P}_{2} \mathrm{O}_{7}$ levels in approximately $30 \%$ of the uremic patients studied. High circulating levels of $\mathrm{P}_{2} \mathrm{O}_{7}$ could result in the deposition of this compound in tissues, possibly as a calcium or magnesium salt. This in turn could act as a nidus for the precipitation of additional calcium-phosphate compounds.

It would be normally expected that $\mathrm{P}_{2} \mathrm{O}_{7}$ would rapidly be hydrolyzed by pyrophosphatase, however, the present study would show that the deposited $\mathrm{P}_{2} \mathrm{O}_{7}$ is resistant to pyrophosphatase. It is well recognized that certain forms of $\mathrm{P}_{2} \mathrm{O}_{7}$ such as $\mathrm{CuP}_{2} \mathrm{O}_{7}$ (18) and $\mathrm{ZnP}_{2} \mathrm{O}_{7}$ (19) are resistant to enzamatic hydrolysis. However, neither these nor any other trace elements were found to be present in high enough concentrations in uremic visceral calcification to bind more than a small amount of the $\mathrm{P}_{2} \mathrm{O}_{7}$ that was present.

Although magnesium is required for the activation of pyrophosphatase it has recently been suggested that $\mathrm{MgP}_{2} \mathrm{O}_{7}$ may be resistant to hydrolysis by this enzyme (20). The similarity between the infrared pattern of uremic visceral calcification and synthetic $\mathrm{MgP}_{2} \mathrm{O}_{7}$ in association with the high magnesium content of uremic visceral calcium-phosphate deposits would be consistent with the $\mathrm{P}_{2} \mathrm{O}_{7}$ being present as the magnesium salt. If $\mathrm{P}_{2} \mathrm{O}_{7}$ is indeed deposited as $\mathrm{MgP}_{2} \mathrm{O}_{7}$, it seems possible that the hypermagnesemia commonly present in uremic patients (21), rather than a primary disorder of $\mathrm{P}_{2} \mathrm{O}_{7}$ metabolism might be responsible for the accumulation of $\mathrm{P}_{2} \mathrm{O}_{7}$ in soft tissue calcium-phosphate deposits. This may be one mechanism by which hypermagnesemia, which has been shown experimentally to promote calcification (22), could be important in the pathogenesis of uremic visceral calcification. Additional studies are required to better characterize the form in which $\mathrm{P}_{2} \mathrm{O}_{7}$ is deposited and to determine whether $\mathrm{P}_{2} \mathrm{O}_{7}$ deposition possibly as the magnesium salt is the primary or inciting event in the production of visceral calcification in uremic patients or secondarily deposited on a preexisting calcium-phosphate deposit.

\section{ACKNOWLEDGMENTS}

We thank Dottie Goodman and K. Robbins for secretarial assistance.

This work was supported by General Veterans Administration Research funding, National Institutes of Health contract 1-AM-4-2217, Easter Seal Research Foundation Grant R-7223, Shriners Hospital, Chicago; National Institutes of Health Clinical Research Center grant RR-69, and National Science Foundation-Research Applied to National Needs GI-44255.

\section{REFERENCES}

1. Massry, S. G., M. M. Popovtzer, J. W. Coburn, D. L. Makoff, M. H. Maxwell, and C. R. Kleteman. 1968. Intractable pruritus as a manifestation of secondary hyperparathyroidism in uremia. Disappearance of itching after subtotal parathyroidectomy. N. Engl. J. Med. 279: 697-700.

2. Contiguglia, S. R., A. C. Alfrey, N. L. Miller, D. E. Runnells, and R. Z. Le Geros. 1973. Nature of soft tissue calcification in uremia. Kidney Int. 4: 229-235.

3. Caner, J. E. Z., and J. L. Decker. 1964. Recurrent acute (?Gouty) arthritis in chronic renal failure treated with periodic hemodialysis. Am. J. Med. 36: 571-582.

4. Alfrey, A. C., D. Jenkins, C. G. Groth, W. S. Schorr, L. Gecelter, and D. A. Ogden. 1968. Resolution of hyperparathyroidism, renal osteodystrophy and metastatic calcification following renal homotransplantation. N. Engl. J. Med. 279: 1349-1356.

5. Conger, J. D., W. S. Hammond, A. C. Alfrey, S. R. Contiguglia, R. E. Stanford, and W. E. Huffer. 1975. Pulmonary calcification in chronic dialysis patients. Clinical and pathologic studies. Ann. Intern. Med. 83: 330-336.

6. LeGeros, R. Z., S. R. Contiguglia, and A. C. Alfrey. 1973. Pathological calcifications associated with uremia. Two types of calcium phosphate deposits. Calcif. Tissue Res. 13: 173-185.

7. Neuman, W. F., and M. W. Nelman. 1958. The Chemical Dynamics of Bone Mineral. Chicago. 35.

8. Alfrey, A. C., L. L. Nunnelley, H. Rudolph, and W. R. Smythe. 1976. A small sample X-ray fluorescence system for medical analysis. Adv. X-ray Anal. In press.

9. Chen, P. S., Jr., T. Y. Toribara, and H. Warner. 1956. Microdetermination of phosphorus. Anal. Chem. 28: 1756-1758.

10. David, S. D., S. Sakai, J. Granda, J. S. Cheigh, R. R. Riggio, K. H. Stenzel, and A. L. Rubin. 1973. Role of 
pyrophosphate in renal osteodystrophy. Trans. Am. Soc. Artif. Intern. Organs. 19: 440-445.

11. Armstrong, D., D. Van Warner, and C. C. Solomons. 1975. Serum pyrophosphate levels in osteogenesis imperfecta. J. Clin. Chem. 21: 104-108.

12. Greenfield, D. J., J. D. Termine, and E. D. Eanes. 1974. A chemical study of apatites prepared by hydrolysis of amorphous calcium phosphates in carbonate-containing aqueous solutions. Calcif. Tissue Res. 14: 131-138.

13. Francis, M. D. 1969. The inhibition of calcium hydroxyapatite crystal growth by polyphosphonates and polyphosphates. Calicf. Tissue Res. 3: 151-162.

14. Russell, R. G. G., R. C. Muhlbauer, S. Bisaz, D. A. Williams, and H. Fleisch. 1970. The influence of pyrophosphate, condensed phosphates, phosphonates and other phosphate compounds on the dissolution of hydroxyapatite in vitro and on bone resorption induced by parathyroid hormone in tissue culture and in thyroparathyroidectomized rats. Calcif. Tissue Res. 6: 183-196.

15. Terman, D. S., A. C. Alfrey, W. S. Hammond, T. Donnedlinger, D. A. Ogden, and J. H. Holmes. 1971. Cardiac calcification in uremia. A clinical, biochemical and pathologic study. Am. J. Med. 50: 744-755.

16. Katz, A. I., C. L. Hampers, and J. P. Merrill. 1969. Secondary hyperparathyroidism and renal osteodystrophy in chronic renal failure. Analysis of 195 patients, with observations on the effect of chronic dialysis, kidney transplantation, and subtotal parathyroidectomy. Medicine (Baltimore). 48 : 333-374.

17. Russell, R. G. G., S. Bisaz, and H. Fleisch. 1969. Pyrophosphate and diphosphonates in calcium metabolism and their possible role in renal failure. Arch. Intern. Med. 124 : 571-577.

18. Wöltgens, J. H. M., S. L. Bonting, and O. L. Bijvoet. 1973. Inorganic pyrophosphatase in mineralizing hamster molars. III. Influence of diphosphonates. Calcif. Tissue Res. 13 : 151-157.

19. Wöltgens, J., and W. Ahsmann. 1970. Determination of orthophosphate in the presence of inorganic pyrophosphate in the assay of inorganic pyrophosphatase activity. Anal. Biochim. 35 : 526-529.

20. Cathala, G., and C. Brunel. 1973. L'Activité pyrophosphatasique de la phosphatase alcaline du cerveau. Biochim. Biophys. Acta. 315: 73-82.

21. Alfrey, A. C., N. L. Miller, and D. Butkus. 1974. Evaluation of body magnesium stores. J. Lab. Clin. Med. 84 : 153-162.

22. Whittier, F. C., and R. M. Freeman. 1971. Potentiation of metastatic calcification in vitamin D-treated rats by magnesium. Am. J. Physiol. 220: 209-212. 